\title{
EFFECTIVE CATION-EXCHANGE CAPACITY IN FINNISH MINERAL SOILS
}

\author{
Armi KaIla \\ University of Helsinki, Department of Agricultural Chemistry
}

Received May 17, 1971

\begin{abstract}
Effective CEC of 230 mineral soil samples was estimated as sum of $(\mathrm{Ca}+\mathrm{Mg})$ and $(\mathrm{Al}+\mathrm{H})$ displaced by $\mathcal{N} \mathrm{KCl}$. The mean values as me/100 $\mathrm{g}$ of soil were, in the surface samples, $15.9 \pm 2.0$ in 46 clay soils, $8.9 \pm 1.3$ in 21 silt and loam soils, and $8.3 \pm 1.1$ in 39 sandy soils. In samples from the deeper layers the corresponding means were $16.3 \pm 2.3$ in 54 clay soils, $5.6 \pm 0.9$ in 21 silt and loam soils, and $2.5 \pm 0.5$ in 49 sandy soils.

In surface samples of clay soils the mean effective CEC was about two thirds, in sandy soils of deeper layers about one third, and in all other groups about one half of the corresponding average potential CEC determined by neutral ammonium acetate.

In the total material in which claycontent ranged from 0 to $95 \%$, organic $C$ from 0.1 to $8.7 \%$, soil $\mathrm{pH}$ from 3.3 to 7.5 , and oxalate soluble Al from 1.4 to $47.9 \mathrm{mmol} / 100 \mathrm{~g}$, the "effective CEC" depended mostly on clay content: the partial correlation coefficient $r=$ $0.90 * * *$, and the standard partial regression coefficient $\beta=0.84$. The corresponding coefficients for the relationship between the "effective CEC» and the content of organic $C$ were $r=0.55^{* * *}$ and $\beta=0.29$, soil $p H r=0.35 * * *$ and $\beta=0.16$, and oxalate soluble Al $r=-0.13$ and $\beta=-0.06$.

The positive effect of liming on effective CEC, particularly, in coarser textured acid soils high in organic matter was emphasized.
\end{abstract}

The figure for the cation-exchange capacity (CEC) of a soil largely depends on the method used for its determination, particularly on the $\mathrm{pH}$ of the saturating electrolyte solution (Pratt and Bair 1962, Bhumbla and McLean 1965). In Finnish more or less acid soils estimation of CEC at $\mathrm{pH} \mathrm{7,} \mathrm{or} \mathrm{even} \mathrm{at} \mathrm{pH} 8.2$ as by the Mehlich method, is likely to yield markedly higher values than is the exchange capacity of these soils as they exist in the field. This is the case especially with soils low in clay and high in organic matter, since the CEC of organic matter is almost completely pH-dependent (HELLING et al. 1964). It is also likely that in our acid soils aluminium-hydroxy-polymers block part of the exchange sites of organic and inorganic colloids, in this way decreasing the effective CEC of the soil (KERÄNEN 1946, KaILA 1971). 
In the present paper an attempt is made to study the effective CEC of mineral soils using normal potassium chloride as displacing agent. Statistical methods are employed for evaluation of the importance of various factors responsible to this CEC. Among these variables are soil $\mathrm{pH}$ and the contents of clay, organic $\mathrm{C}$ and oxalate soluble $\mathrm{Al}$.

\section{Material and methods}

The material consists of 230 samples of mineral soils collected from various parts of the country, both from surface soils and from deeper layers. A part of the samples were from virgin soils.

The samples were air-dried and ground to pass the $2 \mathrm{~mm}$ sieve. Thus, in most cases, the moraine soils will be listed as sandy soils, when the samples are classified according to the particle size composition. There were 100 samples of clay soils with at least $30 \%$ of the fraction $<2 \mu$, 42 samples of loam and silt soils, and 88 samples of sandy soils.

Soil $\mathrm{pH}$ was measured in 1 to 2.5 suspension in $0.01 \mathrm{M} \mathrm{CaCl}_{2}$. Organic $\mathrm{C}$ was determined by wet combustion and iodometric titration. The clay content, estimated by pipette method after destruction of organic matter by peroxidation, is expressed as a percentage of this mineral residue. Al was extracted with Tamm's acid ammonium oxalate: the ratio of soil to solution was 1 to 20 , and the period of extraction was two hours. Al was determined by the Aluminon method after destruction of organic matter of the oxalate extract by ignition.

The »effective CEC» was calculated as the sum of $(\mathrm{Ca}+\mathrm{Mg})$ and $(\mathrm{Al}+\mathrm{H})$ extracted from $10 \mathrm{~g}$ soil by five successive treatments with $20 \mathrm{ml}$ of $\mathrm{N} \mathrm{KCl}$. ( $\mathrm{Ca}+\mathrm{Mg}$ ) was determined by versenate titration, and $(\mathrm{Al}+\mathrm{H})$ by titration with $0.1 \mathrm{~N} \mathrm{NaOH}$.

A potential CEC was estimated by summation of exchangeable $\mathrm{Ca}, \mathrm{Mg}, \mathrm{K}, \mathrm{Na}$ and $(\mathrm{Al}+\mathrm{H})$ displaced by neutral $\mathrm{N}$ ammonium acetate.

\section{Results}

The groups of soil samples are characterized by data in Table 1. The surface soils represent top layer down to about $20 \mathrm{~cm}$, and the samples of deeper layers are mainly from the depths between $20 \mathrm{~cm}$ and $60 \mathrm{~cm}$.

The $\mathrm{pH}$-values of the samples ranged from $\mathrm{pH} 3.3$ in a virgin Litorina soil to $\mathrm{pH} 7.5$ in a couple of samples from the vicinity of a limestone quarry. In most samples the $\mathrm{pH}$ varied from 4.5 to 6 with a mean value of about $\mathrm{pH}$ 5. The limits of the content of org. $\mathrm{C}$ were in the surface samples 1.0 and $8.7 \%$, and in the samples from deeper layers 0.1 and $2.4 \%$. The relatively high upper limit in the latter group belonged to Litorina soils rich in organic matter even in deeper layers. The highest clay content was $95 \%$ of the mineral fraction. Oxalate soluble $\mathrm{Al}$, supposed to be free hydrous aluminium oxides, ranged from 1.4 to $47.9 \mathrm{mmol} / 100 \mathrm{~g}$. In the sandy soils, the accumulation of aluminium compounds in the B-horizon of Podzols is likely to be responsible for the high mean content in these deeper layers.

The meffective CEC» in these soils determined by summation of $(\mathrm{Ca}+\mathrm{Mg}$ ) and $(\mathrm{Al}+\mathrm{H})$ displaced by unbuffered $\mathrm{N} \mathrm{KCl}$ varied largely in each group of the samples (Table 2). The highest values are in the clay soils, and no marked difference seems to be 
Table 1. Soil samples

\begin{tabular}{|c|c|c|c|c|c|}
\hline & $\begin{array}{c}\text { Number } \\
\text { of } \\
\text { samples }\end{array}$ & $\mathrm{pH}^{*}$ & Org. C \%* & Clay \%* & $\begin{array}{l}\text { Oxalate soluble } \\
\mathrm{Al} \\
\mathrm{mmol} / 100 \mathrm{~g}^{*}\end{array}$ \\
\hline \multicolumn{6}{|l|}{ Surface soils } \\
\hline Clay & 46 & $5.0 \pm 0.1$ & $4.0 \pm 0.5$ & $50 \pm 5$ & $14.9 \pm 1.8$ \\
\hline Silt and loam & 21 & $5.0 \pm 0.3$ & $3.7 \pm 0.6$ & $21 \pm 3$ & $12.2 \pm 3.6$ \\
\hline Sandy soils & 39 & $4.9 \pm 0.2$ & $4.1 \pm 0.6$ & $11 \pm 2$ & $10.8 \pm 1.4$ \\
\hline \multicolumn{6}{|l|}{ Deeper layers } \\
\hline Clay & 54 & $5.3 \pm 0.2$ & $1.0 \pm 0.2$ & $57 \pm 5$ & $10.2 \pm 1.2$ \\
\hline Silt and loam & 21 & $5.1 \pm 0.3$ & $0.7 \pm 0.2$ & $21 \pm 3$ & $6.5 \pm 1.5$ \\
\hline Sandy soils & 49 & $4.8 \pm 0.1$ & $0.9 \pm 0.1$ & $6 \pm 2$ & $12.9 \pm 3.2$ \\
\hline
\end{tabular}

* Mean values with the confidence limits at 95 per cent level

Table 2. "Effective $\mathrm{CEC}$ " as sum of $(\mathrm{Ca}+\mathrm{Mg})$ and $(\mathrm{Al}+\mathrm{H})$ displaced by $\mathrm{N} \mathrm{KCl}$ and potential $\mathrm{CEC}$ estimated by neutral ammonium acetate

\begin{tabular}{lrrrr}
\hline & \multicolumn{2}{c}{ "Effective CECm me/100 } \\
mean* & range & \multicolumn{2}{c}{$\begin{array}{c}\text { Potential CEC me/100 g } \\
\text { mean* }\end{array}$} & range \\
\hline & & & & \\
Surface soils & & & & \\
Clay & $15.9 \pm 2.0$ & $9.1-35.9$ & $30.3 \pm 3.1$ & $14.9-86.7$ \\
Silt and loam & $8.9 \pm 1.3$ & $5.1-15.4$ & $20.3 \pm 2.4$ & $12.0-30.0$ \\
Sandy soils & $8.3 \pm 1.1$ & $3.3-17.6$ & $19.8 \pm 2.2$ & $7.4-36.9$ \\
& & & & \\
Deeper layers & & & & \\
Clay & $16.3 \pm 2.3$ & $6.0-32.3$ & $24.5 \pm 2.6$ & $9.6-41.5$ \\
Silt and loam & $5.6 \pm 0.9$ & $2.1-11.9$ & $11.2 \pm 3.4$ & $5.9-13.7$ \\
Sandy soils & $2.5 \pm 0.5$ & $0.4-10.8$ & $7.8 \pm 1.0$ & $1.8-16.4$ \\
& & & & \\
\hline
\end{tabular}

*Mean values with the confidence limits at 95 per cent level

found between the samples from the surface soils and deeper layers. In the both non-clay groups of the surface samples the »effective CEC» appears to be of the same order of magnitude, but in the samples from the deeper layers the mean »effective CEC» of the sandy soils is lower than that of the silt and loam soils.

These figures for the »effective CEC» did not include exchangeable $\mathrm{K}$ and Na. The sum of these cations displaced by neutral ammonium acetate was, on the average, $1.0 \mathrm{me} /$ $100 \mathrm{~g}$ in the clay samples both from the surface soils and from the deeper layers, $0.7 \mathrm{me} /$ $100 \mathrm{~g}$ in the surface samples and $0.4 \mathrm{me} / 100 \mathrm{~g}$ in the samples from the deeper layers of 
silt and loam soils. In the sandy soils the means of these sums were $0.5 \mathrm{me} / 100 \mathrm{~g}$ in the surface soils and only $0.2 \mathrm{me} / 100 \mathrm{~g}$ in the deeper layers. If these values are taken to represent the average amounts of these cations displaced also by the $\mathrm{KCl}$ solution, it is found that the means of the meffective CEC» reported in Table 2 are about 93 to 95 per cent of the wreal» effective CEC-values in these soil groups.

The means of the potential CEC determined by neutral ammonium acetate are in these soil groups markedly higher than the corresponding figures for the effective CEC. Their difference is more than $10 \mathrm{me} / 100 \mathrm{~g}$ in the surface soils, and about 5 to $7 \mathrm{me} / 100 \mathrm{~g}$ in the samples from the deeper layers. There are some samples of acid clay soils with the potential CEC even more than $25 \mathrm{me} / 100 \mathrm{~g}$ higher than the corresponding effective CEC. The absolute difference tends to be highest in the clay soils from the surface layer, but relatively, the difference is largest in the soils of a coarser texture, particularly in the sandy soils from the deeper layers. In this group the average effective CEC is only about one third of the mean CEC-value determined by neutral ammonium acetate.

In the clay soils, organic matter does not seem to contribute markedly to the meffective CEC», since the mean values and ranges are almost equal in the surface samples, relatively rich in organic matter, and in the samples from the deeper layers. In the non-clay soils, organic matter may play a more important role in this respect, because the mean values of the "effective CEC" are markedly higher in the surface samples even in silt and loam soils which had an equal average clay content in the surface and subsurface soils. The very low average »effective CEC» in the sandy soils from deeper layers may be attributed, except to lack of organic matter, also to their very low content of clay.

Table 3. Total and partial correlation coefficients for the relation between the meffective CECm (1), and clay content (2), content of organic C (3), soil pH (4), and content of oxalate soluble Al (5)

\begin{tabular}{|c|c|c|c|c|}
\hline & $\begin{array}{l}\text { Surface soils } \\
106 \text { samples }\end{array}$ & $\begin{array}{c}\text { Deeper layers } \\
124 \text { samples }\end{array}$ & $\begin{array}{l}\text { Non-clay soils } \\
130 \text { samples }\end{array}$ & $\begin{array}{r}\text { Clay soils } \\
100 \text { samples }\end{array}$ \\
\hline $\mathrm{r}_{12}$ & $0.81 * * *$ & $0.93 * * *$ & $0.46 * * *$ & $0.86 * * *$ \\
\hline$r_{12,3}$ & $0.83 * * *$ & $0.93 * * *$ & $0.53 * * *$ & $0.86 * * *$ \\
\hline$r_{12}, 34$ & $0.85 * * *$ & $0.92 * * *$ & $0.53 * * *$ & $0.86 * * *$ \\
\hline$r_{12}, 345$ & $0.83 * * *$ & $0.92 * * *$ & $0.49 * * *$ & $0.85 * * *$ \\
\hline $\mathrm{r}_{13}$ & $0.31 * *$ & 0.02 & $0.74 * * *$ & 0.04 \\
\hline$r_{13,2}$ & $0.43 * * *$ & 0.01 & $0.77 * * *$ & $0.28 * *$ \\
\hline$r_{13}, 24$ & $0.55 * * *$ & 0.11 & $0.82 * * *$ & $0.26^{*}$ \\
\hline$r_{13,245}$ & $0.55 * * *$ & 0.12 & $0.87 * * *$ & $0.30^{* *}$ \\
\hline$r_{14}$ & $0.25 * *$ & $0.34 * * *$ & $0.28 * *$ & $0.25^{*}$ \\
\hline $\mathrm{r}_{14,2}$ & $0.29 * *$ & $0.26 * *$ & $0.24 * *$ & $0.24^{*}$ \\
\hline$r_{14,23}$ & $0.47 * * *$ & $0.28 * *$ & $0.50 * * *$ & $0.22^{*}$ \\
\hline$r_{14}, 235$ & $0.45 * * *$ & $0.28 * *$ & $0.57 * * *$ & $0.25^{*}$ \\
\hline$r_{15}$ & $0.35 * * *$ & -0.06 & -0.17 & $0.28 * *$ \\
\hline$r_{15}, 2$ & 0.04 & -0.04 & -0.09 & 0.05 \\
\hline$r_{15}, 23$ & $-0.20^{*}$ & -0.05 & $-0.40^{* * *}$ & -0.11 \\
\hline$r_{15}, 234$ & -0.09 & -0.04 & $-0.49 * * *$ & -0.16 \\
\hline
\end{tabular}


The relation of the "effective CEC» to the contents of clay and organic $\mathrm{G}$ in these soils was more thoroughly studied by calculating the total and partial linear correlation coefficients between these variables. Also the soil $\mathrm{pH}$ and the content of oxalate soluble $\mathrm{Al}$ were taken into consideration. The 230 soil samples were classified in two ways: 106 surface samples and 124 subsoil samples, or 130 non-clay samples and 100 clay samples. The results are reported in Table 3 .

The correlation between the meffective CECm and the content of clay is relatively close, except in the group of non-clay soils. It was not reduced by elimination of the effects of the content of organic $\mathrm{C}$, soil $\mathrm{pH}$, and oxalate soluble $\mathrm{Al}$.

There is no correlation between the weffective CEC» and organic C in the groups of subsurface soils and clay soils, except, when in the latter group, the effect of clay content is eliminated and a slight connection may be found. Even in the group of surface soils this correlation is rather poor, though the elimination of the effects of the clay content and the soil $\mathrm{pH}$ brings about some increase in the closeness of correlation. Only in the group of non-clay soils, the "effective CEC» seems to be more closely connected with the content of organic $\mathrm{C}$ than with the clay content. In this case, the elimination of the effects of each of the three other variables tends to increase the correlation coefficient between the meffective CEC»" and the content of organic C.

The meffective CEC» is rather poorly correlated with soil $\mathrm{pH}$. In the surface soils and in the non-clay soils the partial correlation coefficients after elimination of the effect of organic $\mathbf{C}$ are, however, markedly higher than in the two other groups.

If oxalate-soluble $\mathrm{Al}$ would be correlated with the amounts of aluminium-hydroxypolymers supposed to block some of the exchange sites in soil, a negative correlation between the "effective CEC" and oxalate soluble $\mathrm{Al}$ would be expected. This is the case only in the non-clay soils after elimination of the effects of organic $\mathrm{C}$ and soil $\mathrm{pH}$.

In the four groups of soil samples the following percentage of variation in the weffective CEC» may be explained by variation in the contents of clay and organic C, and in the other variables studied:

$\begin{array}{llccc}\text { Explained by } & \begin{array}{l}\text { Surface } \\ \text { soils }\end{array} & \begin{array}{c}\text { Deeper } \\ \text { layers }\end{array} & \begin{array}{c}\text { Non-clay } \\ \text { soils }\end{array} & \text { Clay soils } \\ \quad \text { clay } & 66.1 \% & 86.3 \% & 21.4 \% & 73.1 \% \\ \text { clay and C } & 72.2 \% & 86.3 \% & 68.1 \% & 75.2 \% \\ \text { clay, C and pH } & 78.4 \% & 87.4 \% & 76.2 \% & 76.4 \% \\ \text { clay, C, pH and Al } & 78.5 \% & 87.4 \% & 81.8 \% & 77.0 \%\end{array}$

Only in the group of non-clay soils with a clay content ranging from 0 to $30 \%$, variation in the total amount of organic $\mathrm{C}$ seems to be of importance in explaining the variation in the meffective CEC». Even in the group of surface soils, relatively rich in organic matter, the content of organic $\mathrm{C}$ explains only 18 per cent of the variation left unexplained by the clay content. Alone it explains less than $10 \%$ of the total variation in the meffective CEC» in this group. Soil $\mathrm{pH}$ appears to be of some importance in the groups of surface soils and non-clay soils in which it explains about 22 per cent and about 25 per cent, respectively, of the variation left unexplained by variation in the contents of clay and organic $\mathrm{C}$. In the non-clay soils, the content of oxalate soluble $\mathrm{Al}$ seems to explain almost 
24 per cent of the variation in the "effective CEC» not accounted for by the three other variables.

When these statistical calculations are applied to the whole material of 230 samples, the following total correlation coefficients and partial correlation coefficients after elimination of the effects of all other three variables are found between the "effective CEC» and

$\begin{array}{llllr} & \text { clay } \% & \text { org. C } \% & \text { soil pH } & \text { Al } \\ \text { r total } & 0.87 * * * & 0.25 * * & 0.31 * * * & 0.09 \\ \text { r partial } & 0.90 * * * & 0.55 * * * & 0.35 * * * & -0.13\end{array}$

The part of variation in the meffective CEC» explained by the clay content is $75.5 \%$, and by the content of organic C only $6 \%$. Together they explain $81.0 \%$. All four variables explain $83.6 \%$ of the variation in the meffective CEC».

The relationship between the weffective CEC» as me/100 $\mathrm{g}\left(\mathrm{x}_{1}\right)$ and the percentages of clay $\left(\mathrm{x}_{2}\right)$ and organic $\mathrm{C}\left(\mathrm{x}_{3}\right)$, soil $\mathrm{pH}\left(\mathrm{x}_{4}\right)$ and the content of oxalate soluble $\mathrm{Al} \mathrm{mmol} /$ $100 \mathrm{~g}\left(\mathrm{x}_{5}\right)$ conforms to the following regression equations in non-clay soils, clay soils and in the material of all the 230 samples:

In 130 samples of non-clay soils,

$$
\mathrm{x}_{1}=0.11 \mathrm{x}_{2}+1.49 \mathrm{x}_{3}+1.78 \mathrm{x}_{4}-0.11 \mathrm{x}_{5}-5.84
$$

The coefficient of multiple correlation is $\mathrm{R}=0.90^{* * *}$, and the standard error of estimate is $\mathrm{S}=1.63$.

In 100 samples of clay soils

$$
\begin{aligned}
& \mathrm{x}_{1}=0.35 \mathrm{x}_{2}+0.71 \mathrm{x}_{3}+1.27 \mathrm{x}_{4}-0.13 \mathrm{x}_{5}+1.56 \\
& \mathrm{R}=0.88^{* * *} \text { and } \mathrm{S}=3.75
\end{aligned}
$$

In all 230 samples

$$
\begin{aligned}
& \mathrm{x}_{1}=0.26 \mathrm{x}_{2}+1.14 \mathrm{x}_{3}+1.83 \mathrm{x}_{4}-0.06 \mathrm{x}_{5}-8.62 \\
& \mathrm{R}=0.92^{* * *} \text { and } \mathrm{S}=3.01
\end{aligned}
$$

The relative importance of these four factors affecting the meffective CEC» may be compared on the basis of the standard partial regression coefficients which are the following:

$\begin{array}{lcccc} & \text { clay } \% & \text { org, C } \% & \text { soil pH } & \mathrm{Al} \\ \text { non-clay soils } & 0.25 & 0.77 & 0.30 & -0.25 \\ \text { clay soils } & 0.88 & 0.18 & 0.13 & -0.10 \\ \text { all soils } & 0.84 & 0.29 & 0.16 & -0.06\end{array}$

Thus, in the whole material and in the group of clay soils, clay content is the most important of these variables in this respect, in the former about three times as important as the content of organic $\mathrm{C}$, in the latter about five times. When the material contains clay soils, the effect of $\mathrm{pH}$ is not marked, but in the group of non-clay soils it seems to be of some- 
what higher importance than the content of clay. The oxalate soluble $\mathrm{Al}$ is noteworthy in the samples of non-clay soils.

When the soil samples are classified to surface soils and subsurface soils, the standard partial regression coefficients for the relationship between the »effective CEC» and the clay content is 0.76 in the former and 0.90 in the latter group, whereas the corresponding coefficients between the "effective CEC» and the content of organic C are only 0.32 and 0.05 respectively. In the surface samples the standard partial regression coefficient between the »effective CEC» and soil $\mathrm{pH}$ is 0.26 which indicates that in this group, $\mathrm{pH}$ is almost as important as the content of organic C. In the subsurface soils this coefficient is 0.10 .

\section{Discussion}

There is no evidence that leaching of soil with unbuffered $\mathrm{KCl}$-solution will give a reliable estimate of the CEC of the soil under natural conditions. The salt concentration of the soil solution is markedly lower than one normal, and the $\mathrm{pH}$ at the surface of the soil colloids may differ from that in the $\mathrm{KCl}$ suspension. It is also likely that, because of different displacing power of the cations, results obtained with some other chloride solution would not be equal to the present values for the effective CEC. Yet, it may be supposed that their order of magnitude is closer to the actual CEC of an acid soil in its natural site than the figures determined by solutions buffered to $\mathrm{pH} 7$.

The average $\mathrm{pH}$ value of the 230 soil samples studied was $\mathrm{pH} 5$ in $0.01 \mathrm{M} \mathrm{CaCl}_{2}$ suspension. The mean of the effective CEC, including exchangeable $\mathrm{K}$ and $\mathrm{Na}$, was about $11 \mathrm{me} / 100 \mathrm{~g}$, or almost $9 \mathrm{me} / 100 \mathrm{~g}$ lower than the mean of the potential CEC measured by neutral ammonium acetate. In the samples from the deeper layers poor in organic matter, the effective CEC was, averagely, in the clay soils about two thirds, in the silt and loam soils about one half, and in the sandy soils only about one third of the corresponding mean of the potential CEC. In the surface soils, the effective CEC was, as an average, about one half of the potential CEC. The difference between the potential and effective CEC consists almost completely of $\mathrm{H}^{+}$-ions: in the present work the sums of $\mathrm{Ca}$ and $\mathrm{Mg}$ displaced by $\mathrm{KCl}$ and by neutral ammonium acetate were equal within the errors of determination. Thus, at the expense of $\mathrm{H}^{+}$-ions dissociated from the weak acidic groups of organic matter at the higher $\mathrm{pH}$, the potential $\mathrm{CEC}$ will give a too high estimate of the cation-exchange properties of acid soils.

As could be expected, in these, mainly, rather acid mineral soils the effective CEC appeared to be most closely correlated with the clay content. The correlation with the content of organic $\mathrm{C}$ was, except in the non-clay soils, relatively low. It is not likely that the total content of organic $\mathrm{C}$, or more exactly, of oxidizable $\mathrm{C}$, will be a good indicator of the exchange sites of soil organic matter, particularly, in this material, in which the quality of organic matter varied from poor raw humus of forest soils to mull of cultivated soils. The variation in the quality of clay was probably less marked, because the clay fraction in Finnish soils seems to consist mainly of illites or more or less weathered mica minerals (Soveri 1956, Soveri and HyYPPÄ 1966).

Though it is likely that in our acid soils hydrous $\mathrm{Al}-$ and $\mathrm{Fe}$ oxides are coating soil particles and blocking exchange sites of inorganic and organic material, this could not be proved by the present results. There was, at least in some soil groups a negative corre- 
lation between the »effective CEC» and oxalate soluble $\mathrm{Al}$, but this was low. As discussed elsewhere (KAILA 1971), acid oxalate may not be the best solution for the determination of $\mathrm{Al}$ and $\mathrm{Fe}$ active in decreasing the effective CEC. This is a problem worth of further studies.

The positive correlation between the "effective CEC» and the soil $\mathrm{pH}$ was in all soil groups significant, though rather low in clay soils and samples from deeper layers in which the clay content was the most important factor affecting the effective CEC. Thus, liming particularly of coarser textured acid soils high in organic matter will increase the effective CEC. In a field trial on fine sand soils the author found that 16 months after application of $0,4000,8000$, or $16000 \mathrm{~kg} \mathrm{CaCO}_{3} / \mathrm{ha}$, the soil $\mathrm{pH}$ was $4.9,5.2,5.6$, and 6.2 , respectively, and the respective meffective CEC-values» were $7.6,8.5,9.4$, and $11.5 \mathrm{me} / 100 \mathrm{~g}$. The content of organic $\mathrm{C}$ in this soil was about $3 \%$.

\section{REFERENCES}

Bhumbla, D. R. \& Mclean, E. O. 1965. Aluminum in soils VI. Soil Sci. Soc. Amer. Proc. 29: 370-374. Helling, C. S. Chesters, G. \& Corey, R. B. 1964. Contributions of organic matter and clay to soil cationexchange capacity affected by the $\mathrm{pH}$ of the saturating solution. Ibid. $28: 517-520$.

Karl., A. 1971. Aluminium and acidity in Finnish soils. J. Sci. Agric. Soc. Finland 43: 11-19

KerÄnen, T. 1946. Kaliumista Suomen maalajeissa. Summary: On potassium in Finnish soils. Acta Agr. Fenn. 63.

Pratt, P. F. \& Bair, F. L. 1962. Cation-exchange properties of some acid soils of California. Hilgardia 33: 689-706.

Soveri, U. 1956. The mineralogical composition of argillaceous sediments of Finland. Ann. Acad. Scient. Fenn. A III 48.

Soveri, U. \& HYYPPÄ, J. M. 1966. On the mineralogy of fine fractions of some Finnish glacial tills. State Inst. Tech. Res. Finland, Publ. 113.

\section{SELOSTUS}

\section{KIVENNÄISMAITTEMME EFEKTIIVINEN KATIONINVAIHTOKAPASITEETTI}

\section{Armi Kaila}

rliopiston maanviljelyskemian laitos, Viikki

Efektiivinen kationinvaihtokapasiteetti (KVK) määritettiin 230 kivennäismaanäytettä käsittävästä aineistosta $1 \mathrm{n} \mathrm{KCl-liuokseen} \mathrm{vaihtuvan}(\mathrm{Ca}+\mathrm{Mg}): \mathrm{n}$ ja $(\mathrm{Al}+\mathrm{H}): \mathrm{n}$ summana. Keskiarvot me/100 g:na olivat pintanäytteissä $15.9 \pm 2.0$ savimaissa, $8.9 \pm 1.3$ hiesu- ja hiuemaissa ja $8.3 \pm 1.1$ hieta- ja hiekkamaissa, joihin sisältyvät myös moreeninäytteet. Syvempien kerrosten näytteissä keskiarvot olivat $16.3 \pm 2.3$ savimaissa, $5.6 \pm 0.9$ hiesu- ja hiuemaissa sekä $2.5 \pm 0.5$ hieta- ja hiekkamaissa. Nämä arvot vastasivat 93-95 \% keskiarvoista, joissa myös vaihtuva $\mathrm{K}$ ja $\mathrm{Na}$ olivat mukana.

Pintamaissa efektiivinen KVK oli yli $10 \mathrm{me} / 100 \mathrm{~g}$ pienempi kuin potentiaalinen KVK, joka määriteltiin tavanmukaisella neutraalilla $1 \mathrm{n}$ ammoniumasetaatilla. Syvemmissä kerroksissa vastaava ero oli keskim. 5-7 me/100 g. Pintakerroksen savimaissa efektiivinen KVK oli noin 2/3, syvempien kerrosten hieta- ja hiekkamaissa noin $1 / 3$ ja muissa ryhmissä noin puolet vastaavasta keskimääräisestä potentiaalisesta KVK:sta.

Efektiivinen KVK riippui voimakkaimmin näytteiden saveksen pitoisuudesta, lukuunottamatta karkeampien maitten ryhmää, jossa orgaaninen hiili näytti olevan tärkein efektiiviseen KVK:in vaikuttava muuttuja. Maan pH vaikutti selvästi, joskaan ei kovin voimakkaasti sekä koko aineiston että eri ryhmien 
efektiivisen KVK:n vaihteluihin. Sen sijaan ei voitu selvästi osoittaa, että oksalaattiin uuttuva Al olisi, maan orgaanisia ja epäorgaanisia vaihtokohtia blokeeraavien Al-hydroksidi-polymeerien kanssa korreloiden, vähentänyt efektiivistä KVK:ta.

Kiinnitettiin huomiota kalkituksen vaikutukseen etenkin karkeitten, happamien ja runsaast orgaanista ainesta sisältävien maitten efektiivisen KVK:n kohottajana. 